\title{
A Fragile Cradle: Writing Jewishness, Nationhood, and Modernity in Cairo, 1920-1940
}

Dario Miccoli

\begin{abstract}
On the basis of literary texts by four Jewish writers (Georges Cattaui, Emile Mosseri, Albert Staraselski, and Lucien Sciuto), this article tries to understand the models of Jewish cultural and political identity circulating in Cairo during the monarchic period, investigating the intellectual atmosphere of interwar Egypt and the numerous ways in which the Cairene Jewish middle and upper classes narrated their lives vis-à-vis their own ethnoreligious community, Egypt, Europe, and Zionism. Literary representations of Jewishness, nationhood, and modernity suggest that living in Egypt as a Jew meant belonging not only to a (semicolonial) national space, to whose imagination these four writers contributed, but also to a wider Mediterranean lieu de savoir (site of knowledge), at the crossroads of past ethnoreligious legacies and novel feelings of cultural and political belonging.
\end{abstract}

Key words: Egyptian Jews, modernity, bourgeoisie, literature

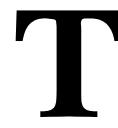

his is a history of forgotten books and little-known Jewish writers. Its four protagonists lived in Cairo in the interwar years-following the end of British colonial rule (1882-1922) and the establishment of a constitutional monarchy that was to last up until the Free Officers' Revolution of 1952-and wrote poems, pamphlets, and journalistic essays. Two of them-Georges Cattaui ${ }^{1}$ and Emile Mosseri-belonged to renowned elite families that had been living in Egypt for generations and were deeply involved in the

Dario Miccoli, "A Fragile Cradle: Writing Jewishness, Nationhood, and Modernity in Cairo, 1920-1940," Jewish Social Studies: History, Culture, Society n.s. 21, no. 3 (Spring/Summer 2016): 1-30. Copyright (C) 2016 The Trustees of Indiana University. doi:10.2979/jewisocistud.21.3.01 
country's sociopolitical arena. The others were more recent arrivals: Lucien Sciuto, a Jew born in late Ottoman Thessalonika who had migrated to Egypt in the 1920s, and Albert Staraselski, the descendant of an Ashkenazi family that had settled in Cairo at the end of the

Jewish

Social

Studies

Vol. 21

No. 3 nineteenth century. Taken together, these four exemplify the vibrant intellectual atmosphere of interwar Egypt and the numerous ways in which the Cairene Jewish middle and upper classes narrated themselves vis-à-vis their own ethnoreligious community, Egypt, Europe, and Zionism. Because of their different biographies and intellectual approaches, and even though they were not ordinary people, these writers reflect "the rise of a newly educated middle-class audience of notables, civil servants and professionals," and their books may be regarded as "carrier[s] of relationships" that shed light on the cultural history of Egyptian Jews.

On the basis of literary texts by Cattaui, Mosseri, Staraselski, and Sciuto, in this article I will try to understand which models of Jewish cultural and political identity circulated in Cairo, and in Egypt at large, during the monarchic period. In doing so, I hope to contribute to a growing body of scholarship on early twentieth-century Middle Eastern Jewish intellectuals in places such as Egypt, Palestine, and Iraq. More specifically, in the last few years the category of Arab Jewishness has often been evoked by scholars to write a relational history of those Jews, Muslims, and Christians who lived in the postOttoman Middle East and North Africa and took part in its cultural, political, and social life. Some historians have also approached this topic from a more contemporary perspective, with an eye to the Palestinian-Israeli conflict and the goal of showing how relations between Jews and Arabs can be more productive and less tense than those dominating the region since the creation of the state of Israel in 1948. ${ }^{3}$ Nonetheless, despite its usefulness, the category of Arab Jewishness has to be handled with caution and through a close textual reading, so as to avoid imposing on all Middle Eastern and North African Jews a label that sometimes reflects current political preoccupations rather than the reality of specific times and places. ${ }^{4}$

In this respect, the Jews of interwar Cairo are a pertinent case, since they show how the Jews of the post-Ottoman Middle East often lived at the crossroads of different national, linguistic, and cultural arenas that went beyond notions of Arabness and Arabic language. In the works of the four writers that I will investigate, living in Egypt as a Jew meant being part of both a (semicolonial) national space, to whose imagination the Jews were contributing, and a wider Mediterranean lieu de savoir (site of knowledge), extending from Cairo to 
Paris, in which ideas, books, and people circulated. This latter space lay at the crossroads of past ethnoreligious legacies and novel feelings of national and cultural belonging.

It is worth remembering that until the 1840s, only about five thousand Jews lived in Egypt, mainly in the old Jewish quarter of Cairo. The opening of the Suez Canal (1869) and the subsequent economic expansion prompted the immigration of thousands of Jews to Egypt from all over the Ottoman Empire and the eastern Mediterranean, the Balkans, and southern Europe. ${ }^{6}$ As in many other cities of the region, the System of Capitulations ${ }^{7}$ and the protected status of many Jews facilitated the improvement of their socioeconomic condition and led to the formation of a large Jewish bourgeoisie in Alexandria and Cairo, places where the vast majority of Egyptian Jews lived. ${ }^{8}$ Though there are a few studies on Arabic-speaking Jewish journalists and writers-primarily Ya'qub Sanu' and the Karaite Murad Faragthe history of how modernity, nationalism, and middle-class formation influenced the Jews who lived in colonial and monarchic Egypt has only recently attracted the interest of historians. ${ }^{9}$ On a related point, although scholars have discussed various aspects of the Egyptian past concerning women, notions of femininity, and motherhood, ${ }^{10}$ only in the last few years have Egyptian male identity and the effendi come to the attention of historical analysis.

The term effendi-originally an honorary title used throughout the Ottoman Empire, which can be translated as "lord" or "master"referred to a man who belonged to an educated middle class of bureaucrats, professionals, employees, and students. ${ }^{11}$ Furthermore, it symbolized a way of being Egyptian and modern that implied a set of social and cultural performances inscribed in both a colonial and an urban "field of hegemonic masculinity within which and against which particular national identities vied for definition, status, and influence." ${ }^{12}$ In this role, the effendi, as opposed to the fellah (peasant), could take advantage of new forms of sociability such as cultural and welfare associations or the modern press and could in turn contribute to the development of a modern Egyptian nation. ${ }^{13}$ But what kind of Egypt was experienced and imagined by the Jewish writers discussed herein? What did its cultural and intellectual arena look like?

\section{Egyptian Jewishness, Francophonie, and Bourgeois Identity}

Between the 1850s and the 1950s, around a thousand books and 150 newspapers were published in French in Egypt, attesting to the 
existence of a lively Francophone intellectual arena and the importance of French as a language of acculturation and modernization, as well as social distinction. ${ }^{14}$ Together with Arabic, French was also the official language of Egyptian administration and diplomacy. ${ }^{15}$

Jewish

The importance of French was even greater among members of minority groups, especially Jews. This was due to the fact that many of them attended French missionary schools or those of the Alliance Israélite Universelle and the Mission Laïque Française. ${ }^{16}$ Furthermore, since many of them had moved to Egypt from non-Arabic-speaking territories like Greece, Anatolia, or Italy at the turn of the century, cultural exchange with Arabophone intellectuals and literates was less pervasive than it was, for example, in Iraq, where Jews made much more important contributions to Arabic literature and journalism. ${ }^{17}$ Nevertheless, Ya'qub Sanu', mentioned above, is noteworthy because of his significant role in late nineteenth-century Egyptian journalism and theater. Mention should also be made of two Syrian-born Jewish intellectuals, Hillel Farhi and Shimon Moyal. The latter lived in Cairo in the early twentieth century with his wife, the Beiruti Jewish journalist Esther Azhari Moyal. More removed from this milieu were the Karaite poets and journalists Murad Farag and Sa'd Malki, editor of the newspaper Al-shams. ${ }^{18}$ Their case illustrates how the Jews, though in small numbers and from a marginal position, contributed to the Nahda, the Arabic cultural and literary renaissance of the turn of the century. ${ }^{19}$

Besides this literary and essayistic material in Arabic, the most significant publications by Jews living in Egypt during the early colonial period consisted of rabbinical studies in Hebrew, such as Neveh shalom (Abode of Peace), published in 1893 by the chief rabbi of Alexandria, Eliyahu Hazan. This points to the existence of yet another Jewish elite, which wished to find a way to modernity within halakhah and Jewish tradition. ${ }^{20}$ As for publications in French, the focus of this study, beginning in the late 1910s and 1920s more Jews started to write in this language, contributing to the development of the Egyptian Francophone intellectual arena. Joseph Cattaoui Pasha was born in 1861 into an old Cairo Jewish family. He was one of the few Jews involved in Egyptian domestic politics and also acted as president of the Jewish community of Cairo from 1925 until his death in $1942 .{ }^{21}$ Cattaoui published books on Egyptian history, including Le régime des Capitulations en Égypte (1927), Coup d'oeil sur la chronologie de la Nation égyptienne (1931), and Le khedive Ismaïl et la dette égyptienne (1935). Earlier in 1919 he had written the pamphlet Pour mes enfants, wherein he discussed issues of morality and public respectability, taking his cue from the 
works of famous European writers and philosophers. ${ }^{22}$ Even Cattaoui's younger brother Adolphe, vice president of the Société Royale de Géographie, authored books, in this case on Egyptology, including his 1918 volume, Champollion et le déchiffrement des hiéroglyphes. ${ }^{23}$ Such "Egyptian[s] of Jewish faith" lated on the one hand to the effendiyah (the effendi class) and on the other to "a virtual community" of French-speaking "bourgeois subjects simultaneously inhabiting national, colonial and diasporic space." ${ }^{25}$ On the shelves of their libraries, volumes by French scholars and novelists like Jules Michelet, Ernest Renan, and Guy de Maupassant stood next to classics of Greek literature by Plutarch and Sophocles, in addition to works by 'Ali Mubarak, al-Maqrizi, and Ibn Khaldun. ${ }^{26}$

The choice to write in French instead of Arabic depended on familial and educational background but was also attributable to the fascination that France and Paris held for the Egyptian and eastern Mediterranean middle classes. I refer here not only-and not mainly - to the real Paris but to an idealized one that by the early twentieth century had become a paradigm of modernity and the capital of a global cultural space. ${ }^{27}$ Jews contributed significantly to the Egyptian press in French-from La Semaine Égyptienne to L'Égypte Nouvelle and La Revue du Caire — and in Arabic and other languages and took part in the foundation of literary circles and associations both inside and outside the boundaries of the Jewish community. ${ }^{28}$ Among these associations was Les Essayistes, established in Cairo in 1924 with the aim of bringing together young poets and writers to discuss their work and other intellectual topics. Les Essayistes lasted until 1934 and published the magazine Un Effort, in which Francophone Jewish authors like Jean Josipovici-son of Albert Josipovici, who wrote the famous Le livre de Goha le simple (1919) together with Albert Adèsand Edmond Jabès published some of their writings. Two other Jewish literary notables, Elian Finbert and Carlo Suarès (who later became a well-known painter and essayist) founded the journal Les Messages de l'Orient in the mid-1920s. ${ }^{29}$

These journals and the social and cultural worlds that orbited around them were part of a wider space of transcommunal intellectual exchange between Jews, Muslims, Italians, Greeks, and others, a lieu de savoir in which a professional or amateur writer could contribute to the Egyptian literary scene and shifting models of gender and class identity were envisioned not only by writing and discussing books but also through novel forms of communication and status display, like advertisements for fashionable department stores or commodities such as cigarettes. ${ }^{30}$ It was also a polyglot society, and authors 
who chose to write primarily or exclusively in French rather than Arabic were still reading and exposed to publications in the latter

[6] language. A significant example of this multilingualism was Israël, a trilingual (French, Arabic, and Hebrew) pro-Zionist newspaper edited

Jewish

Social

Studies

Vol. 21

No. 3 by Albert Mosseri that appeared in Cairo between 1920 and 1939. ${ }^{31}$

More generally, the concerns and even the literary tropes of the Egyptian Jewish writers in French and in Arabic were interrelated and part of a cosmopolitan literary milieu. ${ }^{32}$ This milieu embodied a kind of modernity that was always "uncentred . . . diasporic, a scattered set of processes playing themselves out through the world,"33 not simply a European import but the result of a confrontation between local societies, Europe, and other spaces. ${ }^{34}$ Modernity should here be conceived of as an unfinished business and an itinerary, which encompassed the Arab world, its Jewish subjects, and Europe.$^{35}$ In fact, modernity was related to a Mediterranean space that "was defined precisely by the interaction between new political structures (the colonial state) and older forms of transregional connectivity and authority." ${ }^{36}$ Although rooted in Western culture and the colonial experience, modernity as an imaginative trope thus offered Middle Eastern Jews the possibility of taking part in the development of Arab nationalism and the Nahda, in addition to the elaboration of models of Jewish cultural and political identity that today are largely lost or forgotten. $^{37}$

\section{Georges Cattaui and the (Im)possibilities of Belonging}

"Wake up, Pentaour, and sing a novel song! A song of grace, of euphoria, a song of joy!" These words open Georges Cattaui's 1921 poem Lève-toi, Pentaour! ${ }^{38}$ Cattaui was born in Paris in 1896 in one of the most important families of the Cairo Jewish elite. His father, Adolphea businessman and Egyptologist - was a brother of Joseph Cattaoui. Georges grew up and was educated in France and Egypt, and in the 1920 s, after acting as secretary to King Fuad, he started work as a diplomat in various European capitals. His interest in literature soon took over, though, and in the 1930s he embarked on a full-time career as a writer and literary critic. He converted to Catholicism in the 1920s and spent most of his life first in Egypt and then in Switzerland and France, publishing works on Marcel Proust, the theater of Paul Claudel, T. S. Eliot, and art history. ${ }^{39}$

Lève-toi, Pentaour! is one of Cattaui's earliest works; it uses the pharaonic era as a lens to talk about early twentieth-century Egypt. The 
protagonist is Pentaour, a scribe who wrote an epic poem on the battle of Kadesh, which took place in 1274 B.C.E. between Egypt and the Hittite Empire. At a distance of millennia, in 1921, Pentaour is now asked to resurrect himself and celebrate another milestone of Egyptian history, namely, the nation's upcoming independence and the end of the British occupation and protectorate:

A Fragile Cradle

Dario Miccoli

Egypt, among perishable people,

you kept your essential character for four thousand years,

you are here again without a yoke, without a chain under your sky,

you are here free again ruling over your sand!

On the tomb of Amrou, may, oh Muslim,

this holy day be blessed among your propitious days!

$\cdots$

Blessed be this day, oh Jew, next to the Nile whose waters

took the fragile cradle of Moses;

and you, oh Copt, in your mysterious church,

where the Virgin and the Child rested! ${ }^{40}$

Cattaui evokes a diverse yet unified nation in which Muslims, Jews, and Copts live together peacefully. He stresses that Egypt has maintained its national characteristics against all odds for four thousand years, echoing the idea of Egyptian exceptionalism, vis-à-vis Middle Eastern and Arab countries, which in the 1920s found in pharaonism its most famous ideological expression. According to pharaonism, Egypt had a separate identity, rooted in the country's ancient past and enduring legacy, that went beyond its Islamic heritage and made it different from the rest of the Arab world. ${ }^{41}$ Cattaui's words are also in line with the work of Jewish writers in Arabic, for example, the collection of essays Maqalat Murad: Essais sur la morale, published in 1912 by Murad Farag. ${ }^{42}$ Both should be contextualized in the Egyptian political discourse of the period and in the independence movement led by the liberal nationalist party Wafd, founded in 1919 by Sa'ad Zaghlul.

Cattaui goes on to describe the quintessential Egyptian, the fellah and the fellaha:

In an immense chord, may all our songs blend,

from the most sublime to the most humble: the song

of the resigned fellah who works his field,

the song of the camel driver standing on his camel.

The song that modulates a dark-haired fellaha, who keeps an amphora and goes to the Nile to collect a bit of water. 
Jewish

And I come to you, my Country, as [if I were going] to altars where an entire people gathers in a holy delirium.

And you, prince, be the greeting of Allah upon you! May you be endowed with the olive tree and the palm, oh master whose secure hand made Egypt calm, and was elected father of the fellah! ${ }^{43}$

In line with a nationalist trope that goes back to the fin de siècle and to Ya'qub Sanu', the fellah is a metaphor for the entire Egyptian people, ruled by the wisdom of an almost divine monarch endowed with a "secure hand"-an expression that might refer to the godly yad hazakah (strong/exalted hand) that in Exodus 13:9 is said to have conducted the people of Israel out of Egypt. ${ }^{44}$ From these references, we can interpret Pentaour as the alter ego of Cattaui, who in 1914 had already composed an ode celebrating the proclamation of Hussein Kamel-son of Khedive (viceroy) Isma'il-as sultan of Egypt. ${ }^{45}$ Lève-toi Pentaour! and the ode to Hussein Kamel placed Cattaui within the Francophone intellectual circle around the royal palace of Abdeen, at the same time that it identified him with those early twentieth century (colonial) Jewish writers who-from the Maghreb to Iraq-tried to make space for the Jews in their national and political imaginaries through the use of legendary figures and tropes. ${ }^{46}$

Cattaui's subsequent publication-La promesse accomplie: France Égypte Judée, a collection of poems published in 1922-highlights other, more peculiar sides of his personality. Cattaui was by then not only part of the Cairene Francophone intellectual scene but a public figure in contact with prominent French Catholic artists and intellectuals, from Stanislas Fumet to converts like Max Jacob and Jacques and Raïssa Maritain. ${ }^{47}$ Cattaui himself would convert to Catholicism in 1928, shortly after the death of his parents. ${ }^{48}$ Even though conversions were on the whole quite rare among the Jews of Egypt, Cattaui was not the only member of his family to embrace Christianity: three of his cousins-Charlotte Cattaui, who in the 1920s married the Italian marquess Umberto Lazagna, Jean-Marie Cattaui de Menasce, and Jean de Menasce, both ordained priests-were also converts. ${ }^{49}$

La promesse accomplie appeared in Paris in 1922, but as the author noted in the introductory pages, it was composed in Cairo between 1917 and 1919. The book was dedicated to two personalities who could not have been more different: the British high commissioner 
of Palestine, Herbert Samuel, and the French novelist and politician Maurice Barrès. The title echoed a verse from the book of the prophet Ezekiel, in which God promises to take the people of Israel "into the country for which I lifted up my hand to give it to your fathers" (Ezekiel 20:42). The subtitle, France Égypte Judée, highlighted the three spaces that the author discussed as the most crucial reference points in his life:

A Fragile Cradle

Dario Miccoli

Egypt, because I grew up under your sky

...

Chanaam, because I did not forget

that you were the cradle of my first ancestors,

...

and because I drank milk from your breast,

"France, mother of the arts, the arms and the laws." ${ }^{\text {"5 }}$

For Cattaui there is no contradiction in a triple allegiance to France, Egypt, and Chanaam (Canaan)—a term that, like the Judée (Judea) of the title, immediately invests the land with a biblical and Christian aura. This multiple sense of belonging should also be understood within a framework where notions of nationality and citizenship were being intensely debated in the Middle East and, especially for Jews, "existed on a spectrum ... variously affected by gender, class and personal histories." ${ }^{51}$ In the Egyptian Jewish context, this evokes the journalists Sa'd Malki and Albert Mosseri, who in the 1920s supported both Egyptian nationalism and a moderate Zionism. ${ }^{52}$ For his part, Cattaui liked to think of himself as an exile living far from the "Happy Tell-Aviv [sic], land of spring, fountain of April" 53 and as a proud Egyptian:

Egypt, Egypt! Because I know your immense peace at night, in the fields, when under your summer sky the sistrum of the cricket sounds alone in the silence and makes the infinite space more sensitive. ${ }^{54}$

Cattaui manages to construct an identity of his own that keeps together the effendi and Catholicism, Egyptian nationalism (reflecting his ties to the Egyptian royal house and to King Fuad in particular), and Zionism that, especially after his conversion to Catholicism, was interpreted as "the sign of the imminence of the second advent of Christ." ${ }^{55}$ From this point of view, his Catholicism was an extreme 
means of expressing "a universalist vision" of the human race and "a Francophilia elevated to the rank of religion," tinged with nihilism and a certain relativism. ${ }^{56}$

Jewish

Social Studies

Vol. 21

No. 3

\section{A Modest Fantasy: The Poems of Emile Mosseri}

Together with the Cattaouis, the Mosseris were one of the most important Jewish dynasties of Egypt. Among its members were, for example, Nessim Bey, founder of the Banque Mosseri, and his son Maurice, who for decades acted as vice president of the Jewish community of Cairo. ${ }^{57}$ At the turn of the century Jacques Mosseri had contributed to the recovery of the Cairo Genizah, collecting thousands of documents from the old synagogues of Fustat and Bassatine, and had also published studies on the subject. Finally, as was already noted, Albert Mosseri was the founder of the newspaper Israël. ${ }^{58}$ Like the Cattaouis, the Mosseris were in contact with European intellectuals and scholars living in interwar Egypt, including the Russian-born philosopher Alexandre Koyré, who was employed as a private tutor for the young Denise Mosseri while he was teaching at the Université Fuad Ier of Cairo in the 1930s. ${ }^{59}$

Emile Mosseri was born in Cairo in 1911 and lived there until the 1950s, when he resettled in France. He died in Paris in 1963. A lawyer by training, he wrote several (unpublished) plays and collaborated with magazines like L'Égyptienne and La Réforme Illustrée. ${ }^{60} \mathrm{He}$ was also the cofounder of the Association des Écrivains d'Égypte d'éxpression française. ${ }^{61}$ Whereas Georges Cattaui came to consider writing his primary occupation, Mosseri viewed it as a bourgeois pastime to be cultivated in addition to his professional activity. This is not surprising, since among the elite it was common to engage in amateur writing, which was viewed as a way to display one's familial status and power in the cultural sphere ${ }^{62}$ Perhaps because of his privileged background, Mosseri showed a precocious interest in writing. By 1926, when he was but sixteen, he had already published a poem in L'Égyptienne, the journal of the Egyptian Feminist Union edited by Hoda Sha'arawi. In this poem, Mosseri takes inspiration from a motif from Egyptian popular culture, namely, the fellah:

A fellah, from afar, is still pushing his cart; the silence of the evening is only disturbed by the trembling of a moving tree.

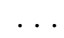


Like the fertile day, I also hope

that I will happily give my work to the land

I will do my duty till the end and I will trust

those who are nobly marching toward the light. ${ }^{63}$

A Fragile Cradle

Mosseri delineates the contours of a man ready to give himself to the land (terre), envisioned as both a real and imagined place where the poet can find solace. Like the 1919 pamphlet Pour mes enfants by Joseph Cattaoui, Mosseri's poem argues that every man is destined to fulfill a duty in order to take his place in the world and help "those who are nobly marching toward the light." And as in the case of Georges Cattaui's Lève-toi, Pentaour! and other Egyptian works of the time, the fellah and the work of the land entail profound national meanings. ${ }^{64}$

Mosseri's most important literary achievement was the publication of a collection of poems, La ballade de la rue, in 1930. In the preface to the book, the author explains how this was "a caprice, a fantasy" written by a man who-even though still very young-was not anymore, "alas!, in the age where one still has illusions about himself." Mosseri seems to have believed that his book would not find success, not least because "dealing with an Egyptian writer, is it not like preaching in the desert?" ${ }^{65}$ For the author, Egypt is a marginal and peripheral space from which he is happy to present his book as a personal accomplishment that will not interest anyone outside that country. Even though this follows well-established literary formulas intended to present the author as a modest and sober gentleman, it might be connected to a form of internalized orientalism whose origins lay also in the Western (ized) education that Mosseri-and a great many Middle Eastern and North African Jews of his generation-received. ${ }^{66}$

Interestingly enough, many of the poems in La ballade de la rue combine national motifs with descriptions of the author's life and feelings. In "J'ai marché quelque soir," Mosseri describes how:

I marched one night when the moon was round, in the temple of the gods of Thebes and Luxor.

...

I passed under your shadow at this hour when everything sleeps, and I thought that just like the priest of Hathor

a people followed me, enlivening the blonde night. ${ }^{67}$

Mosseri goes back to ancient Egypt in order to look for his lost past and identity, wandering around the ruins of Luxor like an "anxious 
soul." ${ }^{68}$ Ancient ruins are a topos of European romantic literature and can be found in the poems of William Wordsworth and George Byron, among others. ${ }^{69}$ In the case of Arabic literature, poems on ruins date back at least to the Middle Ages and function as figures of

Jewish

Social

Studies

Vol. 21

No. 3 contemplation and memory, tied to "the idea of historical lessons [ 'ibar] that ... might mitigate the effects of forgetful and disbelieving human nature." ${ }^{\prime 7}$ In Mosseri's time, ancient Egypt and its archaeological vestiges assumed a clear national connotation and reinforced Egyptian claims to sovereignty. With regard to modern Egyptian literature in Arabic, the poet Ahmed Shawqi, for example, talks about pharaonic ruins as permanent markers of the country's national past. The pharaonic past also inspired great intellectuals like Salama Musa and Muhammad Husayn Haykal and found a visual representation in the renowned 1928 sphinx-like statue Nahdat Misr (The Revival of Egypt) by Mahmud Mukhtar. ${ }^{71}$ Finally, in the case of the Jews, Egypt is related to one of the most important episodes of the Torah, which seemed to reinforce the claim that modern Egyptian Jews were an integral part of Egyptian national history. Thus, the Cairene Jewish writer and Zionist activist Maurice Fargeon wrote in his historical monograph Les Juifs en Egypte (1938) that despite being the land were the Jews had been enslaved, Egypt was also, in the end, where "the sons of Israel came out as a people, becoming a priestly kingdom and a holy nation." 72 This ancestral connection to Egypt was of utmost importance in the 1930s, when notions of citizenship and the status of minorities were being discussed and when the Egyptian liberal system and the Wafd party underwent a crisis. ${ }^{73}$

La ballade de la rue offers a glimpse of Mosseri's inner world and the way he thinks about his most personal feelings, like love or friendship:

Goodbye, my dearest and best friend.

Far from the noises of this world and the vain fatigues.

…

Sleep peacefully, my poor friend, the land is your mother, for you is the eternal rest ...

for us the bitter, exhausting and cruel life! ${ }^{74}$

Here one finds a melancholic man striving to find his place in the world and faced with an inhospitable society: an archetypal romantic figure that can also be traced back to the many articles published at least since the 1930s in Egyptian Jewish magazines like the pro-Zionist La Tribune Juive or to the short stories of Albert Staraselski that I will 
discuss below. In these, the modern world is viewed as a source of anxiety and distress, not serenity. At a larger level, the social changes that were taking place in urban life, and the technological innovations that were spreading throughout cities and continents, provoked intense (trans)national debates on issues of modernity and progress and impact on daily habits and personal relations. ${ }^{75}$ As Mosseri writes in La ballade de la rue,

A Fragile Cradle

Dario Miccoli

Over are the times when your divine lyre

marched the unsure people toward the future,

oh poet who condemns a century of machineries. ${ }^{76}$

Whereas Georges Cattaui eventually faced modernity and its cultural and social consequences in quite a radical manner-think of his conversion to Catholicism and his complex allegiance to France Égypte Judée-Mosseri exemplifies a well-established and global model of bourgeois gentleman with his emphasis on modesty, sobriety, and a careful balance between national and personal feelings, reminiscences of a mythologized Egyptian past, and the contingency of his times. $^{77}$

\section{Zionism and Beyond: Nationhood and Modernity in Albert Staraselski and Lucien Sciuto}

Of course, other paths-different from both Cattaui's and Mosseri's - could be taken in order to face the "century of machineries." From the mid-1930s on, Zionism increased in popularity in Egypt, even though it still appealed only to a minority of Egyptian Jews. ${ }^{78}$ Beneath the development of Zionism and communism and the widespread appeal of such ideologies lay a radicalization of the Egyptian political scene following the death of King Fuad and the signing of the 1936 Anglo-Egyptian Treaty, with which Britain recognized the independence of Egypt and withdrew its troops from all of its territory except the Suez Canal. The Treaty of Montreux the following year abolished the System of Capitulations, which had until then granted juridical and economic advantages to minority groups, including Jews. It was in this period, also as a result of the impact in Egypt of the Arab-Jewish conflict over British Palestine, that movements like Ikhwan al-Muslimun (the Muslim Brotherhood) and Misr al-Fatat (Young Egypt) started to develop and spread. ${ }^{79}$ At the same time, the number of Zionist newspapers, associations, and youth groups-from Ha-ivri 
Ha-tsa'ir (the Young Hebrew) to Benei Akiva (Sons of Akiva)—grew considerably. ${ }^{80}$ It is therefore not surprising that the two men whom I will now introduce were journalists, and their personal and family histories differed consistently from those of Cattaui and Mosseri.

Jewish

Social

Studies

Vol. 21

No. 3

Albert Staraselski was born in Cairo in 1903 to a family of Russian origin that had migrated first to Palestine and then, in the late nineteenth century, to Egypt. From a young age, he wrote in Francophone Egyptian newspapers like La Bourse Égyptienne and was in contact with Les Essayistes. ${ }^{81}$ He was also a member of the executive committee of the Association des Écrivains d'Égypte d'expression française and collaborated with several French publications in Egypt. ${ }^{82}$ While living in France in the early 1920s, Staraselski had been a close collaborator of the Revisionist Zionist leader Vladimir Jabotinsky. Upon his return to Cairo, he became the leader of Revisionism in Egypt and founded the newspaper La Voix Juive.

Staraselski also wrote poetry and in 1930 published Mineures: Petites proses pour personnes pressées, a collection of essays dealing with social and cultural issues related to the modern world. The book was dedicated to the editor of Israël, Albert Mosseri, and was published in the Collection des Écrivains d'Égypte, edited by Raoul Parme, a renowned Francophone poet and writer based in Egypt. ${ }^{83}$ Among the issues that Staraselski discusses in Mineures, modernity and its repercussions feature prominently. The author talks, for instance, about the advent of sound films: "What a miracle! The sound film. . . . The spring of progress does not stop flowing in beneficial streams. Each year and almost each day they give us the joy of a new invention." ${ }^{84}$ Nevertheless, Staraselski admits that "the inner virtue of cinema has always been the darkness of the movie theater, that intimate yet public atmosphere. . . . I wonder whether we could now still enjoy watching mute news stories on a screen. The noise of life has become almost a necessity for us." Staraselski is amazed and proud of modernity and its technological implications yet perplexed when he contemplates its unknown effects: will the bruit de la vie (noise of life) erase the magic of a dark movie theater? Similarly, he worries about the illomened consequences of scientific discoveries: "unknown chemical products come out of the still and menace the human species. And I cannot help but evoke the terrible vision of a war that I once had, while strolling on a Parisian boulevard."

The double face of modernity is already present in the title and its reference to the personnes pressées (people in a hurry) who will read it: people who do not have the time to indulge in reading an entire novel but nonetheless want to amuse themselves with a book that-as 
in the case of Mosseri-is nothing but a collection of mineures, of unimportant and futile words. "The modern man," Staraselski writes in the first pages, "feels that society is heading toward a mechanical ideal and is becoming like a machine of which he will only be a gearwheel." Similar issues of modernity and temporality had already been widely debated in the Egyptian press during colonial times, stressing, however, how middle-class men should indeed lead a scheduled life centered around the principle of tamaddun (civilization, urbanity). ${ }^{85}$ For example, the lawyer and journalist Mustafa Kamil publicly described his daily routine, seeing self-discipline and character formation in positive terms as something that contributed to the regeneration of Egyptian men and foresaw the advent of a new national era. ${ }^{86}$

Contrary to the enthusiastic vision of modernity that Futurist poets and painters had adopted in both Europe and Egypt-for example, Nelson Morpurgo, born in Cairo in 1899 to a Jewish family originally from Istria ${ }^{87}$-Staraselski looks at the world as a place of uncertainty and danger. In this sense, he echoes the feelings of Mosseri and, more generally, of Egyptian (Jewish) newspapers of the time, like Israël and La Tribune Juive, which lamented the effects of life in big cities like Cairo and the threat this life posed especially to younger generations. ${ }^{88}$ In the case of Staraselski, ambivalence toward progress might also have been due to the fact that he was a supporter of Revisionist Zionism, for which modernity, although not to be rejected altogether, represented "a potentially dangerous and decadent development in Jewish history . . . that could prevent the Zionist movement from fulfilling its political aspirations." 89

In contrast to Cattaui's more skeptical vision of the world, Staraselski firmly believes that Zionism is the answer to the problems that the modern world has imposed on Jews. This can be discerned from the numerous articles that he published in La Voix Juive in the 1920s. For example, while commenting on the conversion to Catholicism of Jean-Marie Cattaui de Menasce in the mid-1920s, Staraselski invokes Zionism as the solution to the terrible life that the "painful mass of people that suffer in the hell of their ghettos" were living. At the same time, Zionism could also contribute to solving the problems that assimilation brought, including conversion. Cattaui de Menasce had "brought . . . shame on the name of two great families," becoming Catholic and even being ordained a priest. ${ }^{90}$ But in Staraselski's view, being a respectable Jewish man-and therefore a Zionistimplied taking care of one's family and community and not betraying "the glorious traditions of a people of martyrs." Despite the 
conversion, Cattaui de Menasce would forever remain "a man between two frontiers ... just like the heimatlos [stateless] migrant who

[16] is rejected from one land to another-a veritable sans-patrie [one with no homeland] of religion." 91 However, Staraselski, too, was "a

Jewish

Social

Studies

Vol. 21

No. 3 man between two frontiers," perhaps even more than two: born into an Ashkenazi family that had migrated to Egypt, he was a Zionistyet he never migrated to Palestine-and also a Francophone writer who participated in the cultural and social life of the Cairene middle class. Other Middle Eastern Jewish journalists and Zionist activists faced a similar destiny, including Albert Mosseri, who was born in Cairo and studied in Paris, and the Beiruti Esther Azhari Moyal, who spent her life between Cairo, Istanbul, Jaffa, and Marseille. ${ }^{92}$ Thus, despite the individual paths that each of these men and women took, they all shared a common characteristic: they were "citizens of the world ... who stopped on every shore," ${ }^{, 93}$ or at least citizens of the world that they knew and that for them had always been endowed with many centers, from Egypt and the Land of Israel to France and many other places.

The case of the Zionist activist and journalist Lucien Sciuto is perhaps the most evident example of such a lack of center. Born in Thessalonika in 1868, Sciuto studied at the local schools of the Alliance Israélite Universelle and became one of the most important late Ottoman Jewish journalists, contributing to many newspapers in his hometown and in Istanbul, from the Journal de Salonique to Le Moniteur Oriental. In the aftermath of the 1908 Young Turk Revolution he founded his own newspaper, L'Aurore. In the late 1910s Sciuto moved to Palestine, finally settling in Cairo in 1924, where he resurrected L'Aurore. He died in Alexandria in $1947 .{ }^{94}$ Of the four writers discussed herein, he is the only one who was not born in Egypt and who belonged to an earlier generation. I have included him here to highlight the extent to which he was part of a shared post-Ottoman (Jewish) world in which moving from Istanbul to Cairo did not have the same implications it has today. In a sense, it meant remaining within a shared eastern Mediterranean space whose coordinates had not been fully erased by colonialism and the fall of the Ottoman Empire. Additionally, and perhaps more important, Sciuto's Egyptian writings show the porous borders of the Egyptian Jewish diaspora and the relative ease with which a new migrant could become part of a community that—as Gudrun Krämer has remarked—was always "one and divisible." 95

In addition to his journalistic activity, in Egypt Sciuto took part in the life of associations such as the Société d'Études Historiques Juives 
d'Égypte and published poems and essays in literary magazines. In January 1924 he published "Un îlot, un petit îlot" in L'Égypte Nouvelle. In it, Sciuto describes an imaginary small island in the middle of the sea, where he would live remembering joyful moments spent with his beloved:

Tell me in which seas,

A Fragile Cradle

Dario Miccoli

which far or near seas,

far from the gloomy steamers,

this small green island steeps its rocks.

I wish to live here abandoned,

oh my dear beloved, with

the perfumed memory

of the kiss that you gave me. ${ }^{96}$

In line with much Francophone Egyptian poetry of the time, from Mosseri's La ballade de la rue to Edmond Jabès's 1936 L'obscurité potable, Sciuto proposes the image of an affectionate man ready to sacrifice everything for his beloved. This seems to reflect the shift toward the ideal of romantic love, and love marriage, that had taken place in early republican Turkey and that can be discerned in a number of memoirs and personal recollections by Egyptian Jews who grew up in the 1920s and 1930s. ${ }^{97}$

Sciuto's most important accomplishment during his time in Egypt was his 1938 collection of poems, Le peuple du messie. The book, written "under the Egyptian sky, on the borders of the desert, in a serene and peaceful setting," 98 was dedicated to King Faruq, for whom Sciuto also wrote a passionate epithalamium celebrating his marriage with Queen Farida:

Lord, at the hour when a festive Egypt

celebrates the nuptials of his king,

allow a modest poet

to come to you with flowers in his hands.

Prince surrounded by joy,

that we admire with fervor,

your crown is the love of the people. ${ }^{99}$

Le peuple du messie was conceived as "a cry of sorrow, a hymn of hope," and "a respectful homage to the martyrs of hatred and centuries-old persecutions," the Jews. Sciuto explains how he feels, being attached not to one but to two homelands, the Land of Israel and Greece: 
Under the sky of Zion my soul opened; my eyes opened under the Aegean sky.

Jewish

Social

Studies

Vol. 21

No. 3

From the top of Hermon to the peak of Olympus, my homeland is covered in blue and snow.

$$
\text { ... }
$$

My soul to Judea and my heart to Hellas.

Cities where, as a pilgrim, I dragged my stick,

Athens and Zion, doubly promised land, the eternal light was given to you both by the hand of David and that of Plato. ${ }^{100}$

The idea that Jews have more than one homeland is of course not unique to Sciuto. It resembles Georges Cattaui's invocation of "France, Egypt, Judea" and is, more generally, a feature frequently attributed to Jews, often with potentially negative connotations such as disloyalty toward the state where they live. ${ }^{101}$ Here, though, Sciuto makes it an accident of history and something to be proud of. The author, who was born and grew up in Thessalonika, feels close to both Greece and to Zion: "my soul to Judea and my heart to Hellas." He presents himself as an enlightened man of letters, nurtured in European philosophy yet attached to his ancestral Jewish faith. Sciuto also echoes the idea-common but not unique to a number of Salonikan Jewish writers and historians-that the Jews are part of a shared Mediterranean civilization, of which the more universal and aesthetic model represented by ancient Greece and the particularistic, ethical biblical Israel are two complementary components. ${ }^{102}$ Nevertheless, he could not help seeing that at the time he was writing, 1938, Europe had become quite an inhospitable place for Jews. Where could the people find refuge? In the poem "Islam," evoking the Jews' expulsion from Spain in 1492, he explains:

the green banner [of Islam],

on a tent or over a city,

declares to the man who follows a desert road:

"Come, brother, the door of hospitality

is wide open!"

...

It says: "Oh brothers of race,

let us ask together, kneeling,

that God keep us under his grace,

that he protect us and encourage us,

and that peace may be upon us!"103 
It is in the Islamic world that Jews have found and can still find refuge from persecution. Drawing on the shared Semitic ancestry of Jews and Arabs and on his own life experience, Sciuto reiterates what other early twentieth-century Palestinian and Egyptian Jewish writers and journalists wrote about the profound connection between Jews and the land of Egypt. ${ }^{104}$ Even late Ottoman Jewish writers and journalists had stressed their ties to the empire and the brotherhood that united them to Ottomans of all faiths. ${ }^{105}$ Sciuto's words hint at possible coexistence and cooperation between Jews and Muslims: for him, both are hospitable people who should live together like "brothers of race," regardless of their religion:

whether you are a Muslim or a Christian, do you know who my God is? Do you?-It is your God.

There is but one God for all human beings.

The universe is the book where his name is written. ${ }^{106}$

\section{Of History and Loss}

Only 10 years separate 1938, the year when Lucien Sciuto wrote "Islam," and the Israeli War of Independence, which opposed the newly born state to a coalition of Arab states, among which was the Kingdom of Egypt. Though brief, this time span was enough to begin to separate the Arab world and its Jewish population and to end a history that today seems buried in a remote past. ${ }^{107}$ Reading the poems of Cattaui, Sciuto, and Mosseri and the essays of Staraselski, it is clear that Jews were an integral part of modern Egypt and its rich culture.

Nevertheless, it would be too easy and simplistic to read the writings of these four as evidence for the fact that during the monarchic period Jews and Muslims in Egypt lived in perfect harmony or that Europeans, local Zionists, and Egyptian nationalists were never engaged in conflict. On the contrary, their works originated in the deep ambivalence of the "fragile cradle"-to quote Georges Cattaui's $\mathrm{La}$ promesse accomplie - in which they tried to navigate the turbulence of interwar Egypt. Yet these Jewish writers attest to the existence of a Middle East in which issues of ethnonational, religious, and cultural belonging were debated in ways that now seem almost inconceivable.

Certainly, in comparison to the Karaite Murad Farag or the Iraqi Jewish intellectuals of the 1920s and 1930s, these Francophone writers are less familiar with both Jewish and Islamic literature and tradition. ${ }^{108}$ Nevertheless, they are aware of Egyptian nationalism and of 
the political and intellectual debates of the monarchic years, and they make use of literary tropes-for example, Mosseri's pharaonic ruins-used by writers of the Arabic Nahda as well. At the same time, Europe, conceived of as a land of progress and cultural ferment, is

Jewish

Social

Studies

Vol. 21

No. 3 very close to them, either because of their educational and family backgrounds or for the personal connections that some had with European intellectuals.

For these four, Jewishness is a crucial component of their personal and familial identity, often charged with national meanings: both Egyptian and pro-Zionist in the case of Cattaui and Sciuto, more explicitly Zionist for Staraselski. Far from being a purely ethnonational marker, Jewishness is refashioned as a multifaceted feeling of belonging that enables them to connect to different spaces and epochs. It stretches back to biblical times and to pharaonic Egypt, in turn making it possible for Jews to be inscribed within modern Egyptian nationalism. But it also binds them to the lands of Islam, where some of their ancestors found refuge when they were expelled from the Iberian Peninsula. From this history comes the idea of nationhood as a plural construct that goes beyond one's passport or place of birth, rooted in the many diasporas in which the Jews have lived. Thrilling, charming, but possibly dangerous and tiring, modernityboth as a temporal category exemplified by the times they were living in and as a spatial one that related Cairo to Europe and to the world -is the historical experience against which these writers publicly evaluate and present themselves, their male bourgeois identity, and their social persona as writers and as (Egyptian) Jews. Modernity thus functions as a stage on which they articulate aspects of their identity and try to come to terms with histories that "cannot adequately be gathered into the form of a singular narrative" and whose origins lie in many different cultural and ethnonational landscapes. ${ }^{109}$

If "loss is . . the enabling fiction that energizes the production of history" and "historians . . . always already write in the shadow of loss," 110 then Cattaui, Mosseri, Staraselski, and Sciuto-and others, including Joseph Cattaoui, Carlo Suarès, and Edmond Jabès-are clues that help us recover some of the discarded connections and vanished possibilities with which the history of Middle Eastern Jews is sprinkled. At a distance of a century, their books are testimonies of a moment when, "under the Egyptian sky, on the borders of the desert," 111 it was sometimes possible to think of oneself, and of each other, beyond the national and ethnic categories that have since prevailed. 


\section{Notes}

The research for this article was possible thanks to a Fondation Maison des Sciences de l'Homme/LabexMed Fernand Braudel Fellowship at the Institut de Recherches et d'Études sur le Monde Arabe et Musulman (Aix-Marseille University). I wish to thank Emanuela Trevisan Semi and Ghislaine Alleaume for reading and commenting on earlier drafts and the anonymous reviewers and the editors of this journal for their insightful suggestions. Unless otherwise indicated, all translations are mine.

1 This family name is variously rendered as Cattaui, Cattaoui, or Qattawi. I will use the spelling Cattaui to refer to Georges and Cattaoui for his uncle Joseph, as these are the spellings generally found in the sources.

2 Marwa Elshakry, Reading Darwin in Arabic, 1860-1950 (Chicago, Ill., 2013), 22. The idea of the printed book as a "carrier of relationships" was first proposed by Natalie Zemon Davis, Society and Culture in Early Modern France: Eight Essays (Stanford, 1975), 192.

3 Lital Levy, "Jewish Writers in the Arab East: Literature, History, and the Politics of Enlightenment, 1863-1914" (Ph.D. diss., University of California, Berkeley, 2007); Jonathan Gribetz, Defining Neighbors: Religion, Race, and the Early Arab-Zionist Encounter (Princeton, 2014); Orit Bashkin, New Babylonians: A History of Jews in Modern Iraq (Stanford, 2012). On the notion of Arab Jewishness and its historical meanings, see Emily Gottreich, "Historicizing the Concept of Arab Jews in the Maghrib," Jewish Quarterly Review 98, no. 4 (2008): 433-51; Lital Levy, "Historicizing the Concept of Arab Jews in the Mashriq," Jewish Quarterly Review 98, no. 4 (2008): 452-69; Yehudah Shenhav, The Arab Jews: A Postcolonial Reading of Nationalism, Religion and Ethnicity (Stanford, 2006); and Ella Shohat, "Rupture and Return: Zionist Discourse and the Study of Arab Jews," Social Text 21, no. 2 (2003): 49-74.

4 Lital Levy, "Mi-hu yehudi-'aravi? 'Iyun meshaveh be-toledot ha-sheelah, 1880-2010," Teoryah u-vikoret 38-39 (2011): 101-35; Jonathan Gribetz, “"To the Arab Hebrew': On Possibilities and Impossibilities," International Journal of Middle East Studies 46 (2014): 589-92.

5 On the lieu de savoir, see Christian Jacob, "Introduction: Faire corps, faire lieux," in Lieux de savoir, t. 1: Espaces et communautés, ed. Christian Jacob (Paris, 2007), 17-42. In using this term, Jacob indicates the physical or imaginative spaces in which human knowledge and all kinds of cultural practices are shaped and transmitted.

6 Gudrun Krämer, The Jews of Modern Egypt, 1914-1952 (London, 1989), 57. See also Jacob Landau, Jews in Nineteenth-Century Egypt (New York, 1969); Michael Laskier, The Jews of Egypt, 1920-1970: In the Midst of Zionism, Anti-Semitism and the Middle East Conflict (New York, 1992); Shimon Shamir, ed., The Jews of Egypt: A Mediterranean Society in Modern Times (Boulder, Colo., 1987); and Joel Beinin, The Dispersion of Egyptian 
Jewry: Culture, Politics and the Formation of a Modern Diaspora (Berkeley, 1986).

7 The Capitulations were bilateral acts stipulated in the fifteenth century between the Ottoman Empire and foreign (i.e., European) powers,

Jewish Social Studies

Vol. 21 No. 3 according to which a person protected by one of these foreign powers enjoyed special economic and juridical privileges.

8 Nora Lafi, "The Ottoman Urban Governance of Migrations and the Stakes of Modernity," in The City in the Ottoman Empire: Migration and the Making of Urban Modernity, ed. Nora Lafi et al. (London, 2011), 8-25.

9 See Dario Miccoli, Histories of the Jews of Egypt: An Imagined Bourgeoisie, 1880s_1950s (London, 2015). On Farag, see Sasson Somekh, "Farag, Murad," in Encyclopedia of Jews in the Islamic World, ed. Norman Stillman, 5 vols. (Leiden, 2010), 2: 190; Reuven Snir, “'A Carbon Copy of Ibn al-Balad'? The Participation of Egyptian Jews in Modern Arab Culture," Archiv Orientální 74 (2006): 37-64; Levy, "Jewish Writers," esp. 142-67; and idem, "Edification between Sect and Nation: Murad Farag and al-Tahdhib, 1901-1903," in Intellectuals and Civil Society in the Middle East: Liberalism, Modernity and Political Discourse, ed. Mohammed A. Bamyeh (London, 2012), 57-76. On Sanu', see Ziad Fahmy, "Francophone Egyptian Nationalists, Anti-British Discourse, and European Public Opinion, 1885-1910: The Case of Mustafa Kamil and Ya'qub Sannu'," Comparative Studies of South Asia, Africa and the Middle East 28, no. 1 (2008): 170-83, and Adam Mestyan, "Arabic Theater in Early Khedivial Culture, 1868-1872: James Sanua Revisited,” International Journal of Middle East Studies 46, no. 1 (2014): 117-37.

10 See Beth Baron, Egypt as a Woman: Nationalism, Gender and Politics (Berkeley, 2005); Marilyn Booth, May Her Likes Be Multiplied: Biography and Gender Politics in Egypt (Berkeley, 2001); Margot Badran, Feminists, Islam and Nation: Gender and the Making of Modern Egypt (Princeton, 1995); Selma Botman, Engendering Citizenship in Egypt (New York, 1999); and Omnia El Shakry, "Schooled Mothers and Structured Play: Child Rearing in Turn-of-the-Century Egypt," in Remaking Women: Feminism and Modernity in the Middle East, ed. Lila Abu-Lughod (Princeton, 1998), 126-70.

11 Israel Gershoni, Redefining the Egyptian Nation, 1930-1945 (Cambridge, Engl., 1995), 7-15.

12 Wilcko C. Jacob, Working Out Egypt: Effendi Masculinity and Subject Formation in Colonial Modernity, 1870-1940 (Durham, N.C., 2011), 90-91; Lucie Ryzova, The Age of the Effendiya: Passages to Modernity in National-Colonial Egypt (Oxford, 2014).

13 Michael E. Gasper, The Power of Representation: Publics, Peasants, and Islam in Egypt (Stanford, 2009), 30. For a Middle Eastern overview, see AnneLaure Dupont and Catherine Mayeur-Jaouen, "Monde nouveau, voix nouvelles: États, sociétés, Islam dans l'entre-deux guerres," Revue des mondes musulmans et de la Méditerranée 95-98 (2002): 9-39. 
14 Irène Fenoglio, "Egyptianité et langue française: Un cosmopolitisme de bon aloi," in Entre Nil et sable: Écrivains d'Égypte d'expression française, ed. Marc Kober with Irène Fenoglio and Daniel Lançon (Paris, 1999), 21; idem, "Le français en Égypte: Un capital de distinction," Bulletin du Cedej 24, no. 2 (1988): 179-87.

15 Frédéric Abécassis, "L’enseignement étranger en Égypte et les élites locales (1920-1960): Francophonie et identités nationales" (Ph.D. diss., Aix-Marseille University, 2000), 32-35.

A Fragile Cradle

Dario Miccoli

16 Miccoli, Histories, 20-52, 61-76.

17 Bashkin, New Babylonians, esp. 15-57.

18 Nahem Ilan, "Le-mi no'edah haggadat Farhi? Li-demutam shel yehudim be-Mitsrayim ba-mahazit ha-rishonah shel ha-meah ha-'esrim," Jewish Studies Internet Journal 4 (2005): 35-59, accessed Feb. 26, 2016, http:/ / www.biu.ac.il/js/JSIJ/4-2005/Ilan.pdf; Jonathan Gribetz, "An ArabicZionist Talmud: Shimon Moyal's At-Talmud," Jewish Social Studies 17, no. 1 (2010): 1-30; Lital Levy, "Partitioned Pasts: Arab Jewish Intellectuals and the Case of Esther Azhari Moyal (1873-1948)," in The Making of the Arab Intellectual: Empire, Public Sphere and the Colonial Coordinates of Selfhood, ed. Dyala Hamzah (London, 2013), 128-63. On Farag, see n. 9, above; Sasson Somekh, "Participation of Jews in Modern Arabic Culture, and the Case of Murad Faraj," in Shamir, Jews of Egypt, 130-40; and excerpts from the works of Murad Farag in Moshe Behar and Zvi Ben-Dor Benite, eds., Modern Middle Eastern Jewish Thought (Waltham, Mass., 2014), 48-61.

19 Lital Levy, "The Nahda and the Haskala: A Comparative Reading of 'Revival' and 'Reform,'” Middle Eastern Literatures 16, no. 3 (2013): 300-316.

20 Landau, Jews in Nineteenth-Century Egypt, 93-114; Shlomo Zalman-Havlin, "Ha-yetsirah ha-ruhanit," in Toledot Yehudei Mitsrayim ba-tequfah ha"otmanit, ed. Jacob Landau (Jerusalem, 1988), 245-309; Zvi Zohar, "Ha-yetsirah ha-halakhtit veha-toranit shel rabbanei Mitsrayim bameatayim ha-shanim ha-aharonot," Pe'amim 86-87 (2001): 175-213; idem, "Mishnatam ha-halakhtit shel hokhmei Yisrael be-Mitsrayim ha-modernit," Pe'amim 16 (1983): 65-83; Miccoli, Histories, 93-102.

21 Krämer, Jews of Modern Egypt, 94-97; Beinin, Dispersion, 45-47. On the Société Royale de Géographie, see Donald M. Reid, "The Egyptian Geographical Society: From Foreign Laymen's Society to Indigenous Professional Association," Poetics Today 14, no. 3 (1993): 539-72.

22 Joseph Cattaoui, Pour mes enfants (Paris, 1919). I discuss this pamphlet in Miccoli, Histories, 102-7.

23 Anthony Gorman, Historians, State, and Politics in Twentieth Century Egypt: Contesting the Nation (London, 2003), 18; Yoav Di Capua, Gatekeepers of the Arab Past: Historians and History-Writing in Twentieth-Century Egypt (Berkeley, 2009), 119, 183.

24 Krämer, Jews of Modern Egypt, 95. 
25 Wilcko Jacob, “Overcoming 'Simply Being': Straight Sex, Masculinity and Physical Culture in Modern Egypt," Gender and History 22, no. 3 (2010): 659. More specifically, the Cattaouis had business interests in France and even owned a hotel particulier (townhouse) in Paris, in the rue de

Jewish Social Studies

Vol. 21

No. 3 Monceau where prominent Jewish families like the Ephrussis, the de Rothschilds, and the Camondos also lived; see Edmund de Waal, The Hare with Amber Eyes: A Hidden Inheritance (London, 2010), 34.

26 M. G. Lee, Catalogue de l'importante bibliothèque de feu Joseph A. Cattaui Pacha (Cairo, 1950).

27 Pascale Casanova, La république mondiale des lettres (Paris, 1999), esp. 41-55. On Egyptian Francophone literature-a subject still in need of historical analysis, as noted by Richard Jacquemond, Entre scribes et écrivains: Le champ littéraire dans l'Égypte contemporaine (Arles, 2003), 26-consider Jean-Jacques Luthi, La littérature d'expression française en Égypte, 1798-1998 (Paris, 2000); idem, Entretiens avec des auteurs francophones d'Égypte (Paris, 2008); idem, Anthologie de la poésie francophone d'Égypte (Paris, 2000); idem, Lire la presse d'expression française en Égypte, 1798-2008 (Paris, 2009); and Irène Fenoglio, "L'écriture francophone et sa réception en Égypte entre 1900 et 1950," in Edmond Jabès: L'éclosion des énigmes, ed. Daniel Lançon and Catherine Mayaux (Saint-Denis, 2007), 29-41. See also Christie McDonald and Susan Rubin Suleiman, eds., French Global: A New Approach to Literary History (New York, 2010); H. Adlai Murdoch and Zsusanna Fagyal, eds., Francophone Cultures and Geographies of Identity (Newcastle, 2013); and for a Jewish historical perspective, Celine Piser, "How to Be a French Jew: Ottoman Immigrant Authors in Early Twentieth-Century Paris," Prooftexts 33, no. 2 (2014): 182-221.

28 For an overview of the Egyptian Jewish press, see Ovadiah Yeroushalmy, La presse juive en Égypte, 1878-1952 (Paris, 2007).

29 Luthi, La littérature d'expression, 69, 173-74; idem, Lire la presse, 204-6. On Adès and Josipovici, see David Leslie Parris, Albert Adès et Albert Josipovici: Écrivains d'Égypte d'expression française au début du XXe siècle (Paris, 2010). On the Egyptian years of Jabès, see Daniel Lançon, Jabès l'Égyptien (Paris, 1998).

30 On advertisement, see Relli Shechter, "Reading Advertisements in a Colonial/Developmental Context: Cigarette Advertising and Identity Politics in Egypt, c. 1919-1939," Journal of Social History 39, no. 2 (2005): 483-503.

31 Hagar Hillel, 'Israël' be-Kahir: 'Iton yehudi be-Mitsrayim ha-leumit, 1920-1939 (Tel Aviv, 2004).

32 For a discussion of the literary representation of Egyptian cosmopolitan ism, see Deborah Starr, Remembering Cosmopolitan Egypt: Literature, Culture, and Empire (London, 2009), and Hala Halim, Alexandrian Cosmopolitanism: An Archive (New York, 2013).

33 Andrew Arsan, Interlopers of Empire: The Lebanese Diaspora in Colonial French West Africa (London, 2014), 153. 
34 Nora Lafi, "Mediterranean Connections: The Circulation of Municipal Knowledge and Practices at the Time of the Ottoman Reforms, c. 1830-1910," in Another Global City: Historical Explorations into the Transnational Municipal Moment, 1850-2000, ed. Pierre-Yves Saunier and Shane Ewen (London, 2008), 135-50.

35 Antoinette Burton, "Introduction: The Unfinished Business of Colonial Modernities," in Gender, Sexuality and Colonial Modernities (London, 1999), $1-16$.

36 Jessica Marglin, "Mediterranean Modernity through Jewish Eyes: The Transimperial Life of Abraham Ankawa," Jewish Social Studies 20, no. 2 (2014): 38.

37 Levy, "Nahda"; idem, "Partitioned Pasts." On the relation between modernity and loss, consider Zvi Ben-Dor Benite, "The Sphinx and the Historian,” American Historical Review 116, no. 3 (2011): 638-52, esp. 650-52.

38 Georges Cattaui, Lève-toi, Pentaour! (Cairo, 1921), 1.

39 The figure of Georges Cattaui merits a study of its own. Here I shall only deal with the youthful writings he published in Egypt and the period of his life before his conversion to Catholicism. Information on later periods of his life can be found in Daniel Lançon, "Georges Cattaui ou la France participée," in Kober, Fenoglio, and Lançon, Entre Nil et sable, 87-103; Massimo Danzi, "Georges Cattaui e Gianfranco Contini: Un'amicizia illustrata attraverso il carteggio inedito," Strumenti critici 17, no. 1 (2002): 119-58, esp. 141-46; and idem, “'Cette Égypte inoubliable, inoubliée': Memorie egiziane in una sconosciuta intervista di Giuseppe Ungaretti," in Letteratura, verità e vita, ed. Paolo Viti (Rome, 2005), 629-45.

40 Cattaui, Lève-toi, 2.

41 Consider Israel Gershoni and James P. Jankowski, Egypt, Islam, and the Arabs: The Search for an Egyptian Nationhood, 1900-1930 (Oxford, 1987); Gershoni, Redefining, 54-78; and Donald M. Reid, "Nationalizing the Pharaonic Past: Egyptology, Imperialism, and Egyptian Nationalism, 1922-1952," in Rethinking Nationalism in the Arab Middle East, ed. James P. Jankowski and Israel Gershoni (New York, 1997), 127-49.

42 Levy, "Jewish Writers," 182-83.

43 Cattaui, Lève-toi, 3, 5.

44 Samia Kholoussi, "Fallahin: The 'Mud Bearers' of Egypt's Liberal Age," in Re-Envisioning Egypt, 1919-1952, ed. Arthur Goldschmidt, Amy J. Johnson, and Baraka A. Salmoni (Cairo, 2005), 277-316; Gasper, Power of Representation.

45 Lançon, "Georges Cattaui," 88.

46 See Colette Zytnicki, Les Juifs du Maghreb: Naissance d'une historiographie coloniale (Paris, 2011); Levy, "Mi-hu yehudi-'aravi?"; and Bashkin, New Babylonians.

47 Brenna Moore, "Philosemitism under a Darkening Sky: Judaism in the French Catholic Revival (1900-45)," Catholic Historical Review 99, no. 2 
(2013): 262-97; Frédéric Gugelot, La conversion des intellectuels au catholicisme en France (1835-1935) (Paris, 1998), esp. 169-210. Whereas Max Jacob and Raïssa Maritain were converts from Judaism to Catholicism, Jacques Maritain was born into a Protestant family.

Jewish

Social

Studies

Vol. 21

No. 3

48 Maurice Lugassy, "Albert Cohen: La tentation du Christ," in Cahiers Albert Cohen: Figures de l'étranger 21 (2011): 68.

49 Dominique Avon, Les frères prêcheurs en Orient: Les Dominicains du Caire (années 1910-années 1960) (Paris, 2006), 140-44; Philippe Chenaux, "Jean de Menasce et Georges Cattaui: Deux fils d'Israël parvenus au Christ," in Jean de Menasce (1902-1973), ed. Michel Dousse and JeanMichel Roessli (Freiburg, 1998), 71-77. According to Pietro Lazagnason of Charlotte Cattaui-the conversions of the four were due to their Francophile and Anglophile education, to the agnosticism of some members of their families, and last but not least to their encounters with significant Catholic scholars and intellectuals. See Pietro Lazagna, "Spazi geografici, percorsi familiari," in Mediterranei, ed. Luisa Rossi and Luca Cerretti (Reggio Emilia, 2010), 256-69, kindly given to me by the author.

50 Georges Cattaui, La promesse accomplie: France Égypte Judée (Paris, 1922), 35. The verse "France, mother of the arts, the arms and the laws" (France mère des arts, des armes et des lois) is a quotation from a classic sixteenthcentury poem by the French poet Joachim du Bellay.

51 Sarah Abrevaya Stein, "Citizens of a Fictional Nation: Ottoman-Born Jews in France during the First World War," Past and Present 226, no. 1 (2015): 229.

52 See Beinin, Dispersion, 246, and Hillel, 'Israël' be-Kahir.

53 Cattaui, La promesse, 64.

54 Ibid., 53.

55 Joël Sebban, "Etre juif et chrétien: La question juive et les intellectuels catholiques français issus du judaïsme (1898-1940)," Archives Juives 44, no. 1 (2011), 121 n. 60.

56 Elena Chiti, "Écrire à Alexandrie (1879-1940): Capital social, appartenances, mémoire" (Ph.D. diss., Aix-Marseille University, 2013), 253.

57 Krämer, Jews of Modern Egypt, 41-43; Adam Guerin, "Mosseri Family," in Stillman, Encyclopedia of Jews, 3: 482.

58 Hillel, 'Israël' be-Kahir.

59 I thank Paola Zambelli for giving me this information.

60 Little information on Mosseri's life and literary activities can be detected from his polemical response to a review of his play La vie continue (Emile Mosseri, "Carrefours," L'Égypte Nouvelle, Aug. 1946, p. 9) or from the personal recollections of Roland Bertin-a member of the Association des Écrivains d'Égypte d'éxpression française-available on the website Souvenirs d'Égypte par Albert Pardo, accessed Feb. 26, 2016, http:/ / albert.pardo.free.fr/KANYAMAKAN.htm\#ecriv.

61 Luthi, La littérature d'expression, 221, 254. 
62 Chiti, "Écrire à Alexandrie," 109-10.

63 Emile Mosseri, "La paix du soir," L'Égyptienne, Mar. 1926, p. 40.

64 See Gasper, Power of Representation.

65 Emile Mosseri, La ballade de la rue: Poèmes (Cairo, 1930), 11-12.

66 Aron Rodrigue, "L'exportation du paradigme révolutionnaire: Son influence sur le judaïsme sépharade et oriental," in Histoire politique des Juifs de France, ed. Pierre Birnbaum (Paris, 1990), 221-43.

67 Mosseri, La ballade, 20.

A Fragile Cradle

Dario Miccoli

68 Ibid., 21.

69 Christopher Rovee, "Ekphrasis," in The Encyclopedia of Romantic Literature, ed. Frederick Burwick, 3 vols. (Malden, Mass., 2012), 1: 405-6.

70 Elliot Colla, Conflicted Antiquities: Egyptology, Egyptomania, Egyptian Modernity (Durham, N.C., 2007), 80-82.

71 Gershoni and Jankowski, Egypt, Islam, and the Arabs, 164-90. See also Reid, "Nationalizing the Pharaonic Past," and idem, Whose Pharaohs? Archaeology, Museums, and Egyptian National Identity from Napoleon to World War One (Berkeley, 2002).

72 Maurice Fargeon, Les Juifs en Égypte: Depuis les origines jusqu'à ces jours (Cairo, 1938), 26. For more on Fargeon's history books, see Dario Miccoli, "Moses and Faruq: The Jews and the Study of History in Interwar Egypt, 1920-1940,” Quest: Issues in Contemporary Jewish History 4 (2012): 165-80.

73 Shimon Shamir, "The Evolution of Egyptian Nationality Laws and Their Application to the Jews in the Monarchy Period," in Shamir, Jews of Egypt, 33-67, and see, more generally, Afaf Lufti al-Sayyid Marsot, Egypt's Liberal Experiment, 1922-1936 (Berkeley, 1977).

74 Mosseri, La ballade, 45-46.

75 On Barak, On Time: Technology and Temporality in Modern Egypt (Berkeley, 2013).

76 Mosseri, La ballade, 31.

77 For a depiction of the ideal bourgeois, see Peter Gay, The Bourgeois Experience, Victoria to Freud, 5 vols. (Oxford, 1984), 1: 43.

78 Gudrun Krämer, "Zionism in Egypt, 1917-1948," in Egypt and Palestine: A Millennium of Association (868-1948), ed. Amnon Cohen and Gabriel Baer (New York, 1984), 348-66; Laskier, Jews of Egypt; Ruth Kimhe, Tsiyonut be-tsel ha-piramidot: Ha-tenu'ah ha-tsiyonit be-Mitsrayim, 1918-1948 (Tel Aviv, 2009).

79 Israel Gershoni and James P. Jankowski, Confronting Fascism in Egypt: Dictatorship versus Democracy in the 1930s (Stanford, 2010).

80 Krämer, Jews of Modern Egypt, 198-99; Laskier, Jews of Egypt, 107-10, 164-68; Kimhe, Tsiyonut.

81 See "Nouvelles du groupe," Un effort, Jan. 1931, p. 38, where Staraselski is said to have given a lecture entitled "Les poètes fantaisistes français" at a meeting of Les Essayistes.

82 For example, he wrote the preface to Raoul Fargeon, Silhouettes d'Égypte: Lettrés et mondains du Caire (Cairo, 1931). 
83 Robert Blum, "L'Association des Écrivains d'Égypte d'expression française," Un effort, May 1931, p. 4, cites him as Staraselsky instead of Staraselski. See also Ovadiah Yeroushalmy, "Staraselski, Albert," in Stillman, Encyclopedia of Jews, 4: 414, and Luthi, Lire la presse, 96, 164.

Jewish

84 Albert Staraselski, Mineures: Petites proses pour personnes pressées (Cairo, 1930). The edition of the book that I consulted at the National Library of Israel, Jerusalem, does not have page numbers.

85 On Barak, "Times of Tamaddun: Gender, Urbanity and Temporality in Colonial Egypt," in Women and the City, Women in the City: A Gendered Perspective on Ottoman Urban History, ed. Nazan Maksudyan (New York, 2014), 15-35.

86 Jacob, Working Out, 63.

87 Maria Elena Paniconi, "Nelson Morpurgo e il 'Movimento del Futurismo Egiziano' fra internazionalismo cosmopolita e appartenenza coloniale," in I linguaggi del futurismo, ed. Diego Poli and Laura Melosi (Macerata, 2013), 209-35.

88 Miccoli, Histories, 151-53.

89 Eran Kaplan, The Jewish Radical Right: Revisionist Zionism and Its Ideological Legacy (Madison, Wisc., 2005), vii.

90 Albert Staraselski, "Deux lettres ouvertes à l'abbé Cattaui de MenasceVotre triple péché . . ., La Voix Juive, Sept. 22, 1932, Égypte I.C.17, Archives of the Alliance Israélite Universelle, Paris, France (hereafter AIU). Outraged articles also appeared in Sciuto's L'Aurore, according to Avon, Les frères prêcheurs, 159-60.

91 Albert Staraselski, "La tournée interrompue: Nous n'irons plus au prêche," La Voix Juive, Sept. 29, 1932, Égypte I.C.17, AIU.

92 Lital Levy, "Moyal, Esther Azhari," in Stillman, Encyclopedia of Jews, 3: 487-88.

93 Andrew Arsan, “'Citizens of the World . . Who Stopped on Every Shore': Eastern Mediterranean Migration, Social Thought, and the Diasporic Uses of the Phoenician Past, c. 1880-1940," Mashriq and Mahjar 2 (2013): 73-98.

94 D. Gershon Lewenthal, "Sciuto, Lucien," in Stillman, Encyclopedia of Jews, 4: 274-76; Luthi, Lire la presse, 161.

95 Gudrun Krämer, "Les juifs d'Égypte: Une communauté une et divisible," in Valeur et distance: Identités et sociétés en Égypte, ed. Charles Decobert (Paris, 2000), 189-208.

96 Lucien Sciuto, “Un îlot, un petit îlot," L'Égypte Nouvelle, Jan. 1924, p. 21.

97 Alan Duben and Cem Behar, Istanbul Households: Marriage, Family and Fertility, 1880-1940 (Cambridge, Engl., 1991); Liliane S. Dammond with Yvette M. Raby, The Lost World of the Egyptian Jews: First-Person Accounts from Egypt's Jewish Community in the Twentieth Century (New York, 2007); Miccoli, Histories, 114-17.

98 Lucien Sciuto, Le peuple du messie: Poème et autres poèmes (Alexandria, 1938), 7. 
99 Ibid., 8. The royal wedding was a major social event and the Egyptian Jewish press wrote about it enthusiastically; see, for example, Joseph de Picciotto, "Ce que le Mariage Royal représente pour nous," La Tribune Juive, Jan. 18, 1938, 1, VI 1306, Archive of the Yad Ben-Tzvi Institute, Jerusalem, Israel. De Picciotto was a well-known Alexandrian businessman, a member of the Egyptian Senate since 1924, and a Wafdist sympathizer (Krämer, Jews of Modern Egypt, 83-84).

100 Sciuto, Le peuple, 65, 67.

101 Indeed, this would be one of the accusations against Egyptian Jews after 1948, especially between 1954-year of the so-called Lavon affair-and the 1956 Suez War. See Beinin, Dispersion, 90-117. The Lavon affair was a failed secret Israeli operation in which a group of Egyptian Jews was recruited and asked to put bombs in certain Egyptian and foreignowned venues in Cairo. Those involved in the affair were identified and arrested by the Egyptian government, which initiated a trial that ended with the execution of two. The affair caused great political uproar in Israel and initiated a downward spiral in Israel's relations with Egypt that culminated in the Suez War.

102 Devin Naar, "L'écriture de l'histoire de la 'Jérusalem des Balkans," in Salonique: Ville juive, ville ottomane, ville grecque, ed. Esther Benbassa (Paris, 2014), 139-59. See also Yaakov Shavit, Athens in Jerusalem: Classical Antiquity and Hellenism in the Making of the Modern Secular Jew (Oxford, 1999).

103 Sciuto, Le peuple, 98.

104 See Beinin, Dispersion, 33-36; Miccoli, Histories, 76-82; and idem, "Moses and Faruq." For similar discussions on late Ottoman Palestine, see Gribetz, Defining Neighbors, and Abigail Jacobson, From Empire to Empire: Jerusalem between Ottoman and British Rule (Syracuse, N.Y., 2011), 82-116.

105 Julia Phillips Cohen, Becoming Ottomans: Sephardi Jews and Imperial Citizenship in the Modern Era (Oxford, 2014).

106 Sciuto, Le peuple, 69.

107 Sarah Abrevaya Stein, "Black Holes, Dark Matter, and Buried Troves: Decolonization and the Multi-Sited Archives of Algerian Jewish History," American Historical Review 120, no. 3 (2015): 900-919.

108 Levy, "Jewish Writers"; Bashkin, New Babylonians, esp. 22-37.

109 Timothy Mitchell, “The Stage of Modernity," in Questions of Modernity, ed. Timothy Mitchell (Minneapolis, Minn., 2000), 24.

110 Sumathi Ramaswamy, The Lost Land of Lemuria: Fabulous Geographies, Catastrophic Histories (Berkeley, 2004), 8.

111 Sciuto, Le peuple, 7.

DARIO MICCOLI is research fellow and adjunct lecturer of Modern Hebrew and Jewish Studies in the Department of Asian and North African Studies, Ca' Foscari University of Venice. He is the 
author of Histories of the Jews of Egypt: An Imagined Bourgeoisie, [30] idens-1950s (2015) and La letteratura israeliana mizrahi: Letteratura,
identitamorie degli ebrei del Medio Oriente e Nord Africa (2016).

Jewish (dr.miccoli@gmail.com)

Social

Studies

Vol. 21

No. 3 